\title{
The effect of functional status of the ovaries on the embryological results of controlled ovarian hyperstimulation
}

\section{Wyniki embriologiczne leczenia niepłodności a stan czynnościowy jajników przed kontrolowana hiperstymulacją hormonalna}

\author{
Grzegorz Mrugacz, Cezary Grygoruk, Mirosław Grusza, Karol Ratomski, Piotr Pietrewicz
}

Center for Reproductive Medicine Bocian, Bialystok, Poland

Director of Center: Grzegorz Mrugacz MD

Key words: controlled ovarian hyperstimulation, embryo, infertility, polycystic ovaries.

Słowa kluczowe: hiperstymulacja hormonalna jajników, jajniki, zarodek, niepłodność, policystyczne.

\begin{abstract}
Introduction: Controlled ovarian hyperstimulation is an integral part of infertility treatment. Despite many years of use, some aspects of controlled ovarian stimulation have not yet been clarified, especially the role of the functional status of the ovaries before hormonal stimulation.

Aim of the research: To assess the effect of the functional status of the ovaries on the embryological results of controlled ovarian hyperstimulation.

Material and methods: The retrospective study included female patients treated for infertility. The patients were divided into two groups depending on the ultrasonographic appearance of the ovaries before controlled ovarian hyperstimulation. Patients with small antral follicles $<6 \mathrm{~mm}$ in diameter were selected for group I. Patients with five or more antral follicles $\geq 8 \mathrm{~mm}$ in diameter in each ovary were included in group II. Patients from both groups underwent the same treatment process. We performed a detailed analysis of the number, type and quality of the obtained embryos.

Results: The number of two- and three-blastomere embryos were comparable in the two groups. There were significantly more four-blastomere embryos in group I than II $(p>0.05)$. The numbers of A, C, D quality embryos were comparable between the groups $(p>0.05)$. There were more B quality embryos in group I than II $(p>0.05)$. The embryo growth rate was significantly faster in group I than II.

Conclusions: The results of the present study indicate that the functional status of the ovaries before controlled ovarian hyperstimulation plays a pivotal role in treatment outcome.
\end{abstract}

\section{Streszczenie}

Wstęp: Kontrolowana hiperstymulacja jajników stanowi integralny i najważniejszy element techniki wspomaganego rozrodu. Mimo wielu lat stosowania niektóre aspekty - zarówno podstawowe, jak i kliniczne - nie zostały do tej pory wyjaśnione. Mało uwagi poświęcono ocenie stanu czynnościowego jajników na początku stymulacji gonadotropinami.

Cel pracy: Próba oceny wpływu stanu czynnościowego jajników na wyniki embriologiczne kontrolowanej stymulacji hormonalnej.

Materiał i metody: Retrospektywnymi badaniami objęto pacjentki leczone z powodu niepłodności. Podzielono je na dwie grupy w zależności od obrazu ultrasonograficznego jajników przed rozpoczęciem kontrolowanej hiperstymulacji hormonalnej jajników. Do grupy I zakwalifikowano pacjentki, u których w obrazie ultrasonograficznym jajników stwierdzano jedynie małe pęcherzyki antralne o średnicy nieprzekraczającej $6 \mathrm{~mm}$, a do grupy II te, u których obok małych pęcherzyków antralnych obserwowano również obecność co najmniej 5 pęcherzyków w każdym z jajników o średnicy równej lub przekraczającej $8 \mathrm{~mm}$. W obu grupach zastosowano jednolitą strategię terapeutyczną. Szczegółowej analizie poddano liczbę, rodzaj oraz jakość uzyskanych zarodków.

Wyniki: Analiza rozwoju zarodkowego w drugiej dobie po zapłodnieniu nie wykazała istotnych różnic w średniej liczbie zarodków dwublastomerowych i trójblastomerowych pomiędzy grupami. Znamiennie więcej zarodków czteroblastomerowych uzyskano w grupie I. Nie stwierdzono istotnych statystycznie różnic w średnich wartościach zarodków klasy A, C, D pomiędzy grupą I i II $(p>0,05)$. Jedynie w przypadku zarodków klasy B zaobserwowano różnice istotne statystycznie na korzyść grupy I $(p<0,05)$. W grupie I stwierdzono także szybsze tempo rozwoju zarodkowego.

Wnioski: Uzyskanie odpowiedniego poziomu wyciszenia jajników w momencie rozpoczęcia kontrolowanej stymulacji hormonalnej istotnie wpływa na wyniki embriologiczne. 


\section{Introduction}

Controlled ovarian hyperstimulation $(\mathrm{COH})$ is an integral part of infertility treatment through assisted reproduction techniques (ART). Its main aim is to obtain oocytes with the highest development potential. Despite 25 years of experience, the efficacy of $\mathrm{COH}$ is relatively low, which is reflected in unsatisfactory embryological and clinical treatment outcomes [1] Among the many $\mathrm{COH}$ methods, protocols using gonadoliberin and exogenous gonadotropin agonists have had the most clinical success [2]. Despite many years of use, some aspects of controlled ovarian stimulation have not yet been clarified, especially the role of the functional status of the ovaries at the beginning of gonadotropin stimulation. In light of data regarding the pathophysiology of the female menstrual cycle, it appears that the functional status of the ovaries may be important, because the quality of oocytes in the early gonadotropin-dependent phase determines their subsequent development potential and, consequently, embryological and clinical results.

\section{Aim of the research}

The aim of this study was to assess the effect of the functional status of the ovaries before controlled ovarian hyperstimulation on the embryological results of infertility treatment through assisted reproduction techniques.

\section{Material and methods}

The study included childless married couples treated in 2009-2011 as a result of male infertility using in vitro fertilization (IVF) with intracytoplasmic sperm injection (ICSI). We used data from medical histories and computer databases for retrospective analysis. The couples who qualified for the study included male patients diagnosed with oligoasthenoteratozoospermia, and female patients who fulfilled the following criteria: aged 25-35 years, regular menstrual cycles lasting 21-35 days, normogonadotropic patient, luteinizing hormone (LH) to follicle-stimulating hormone (FSH) ratio less than 1, polycystic ovarian structure on ultrasound image (12 or more follicles with a diameter from $2 \mathrm{~mm}$ to $9 \mathrm{~mm}$ or increased ovarian volume $>10 \mathrm{~mm}^{3}$ ), and body mass index (BMI) between $18 \mathrm{~kg} / \mathrm{m}^{2}$ and $30 \mathrm{~kg} / \mathrm{m}^{2}$.

All qualified patients underwent the same treatment process. In the previous monthly cycle, the female patients took a monophasic contraceptive drug (Marvelon, Organon) from the $5^{\text {th }}$ to the $25^{\text {th }}$ day of the cycle. On day 21 of the cycle, we administered a single intramuscular injection of a long-acting gonadotropin-releasing hormone agonist (GnRHa) (triptoreline; Diphereline SR 3.75 mg, Beaufour Ipsen). After 21 days of GnRHa activity, pituitary desensitization was evaluated by measuring $\mathrm{FSH}, \mathrm{LH}, \mathrm{E}_{2}$ con- centrations in the serum. We adopted the following criteria of obtained desensitization: $\mathrm{E}_{2}$ concentrations $<40 \mathrm{pg} / \mathrm{ml}$ [3] and lack of cysts exceeding $15 \mathrm{~mm}$ in diameter [4]. Hormone concentrations were determined by enzyme immunoassay (Mini Vidas, BioMerieux, France).

On confirmation of pituitary desensitization, gynecological evaluation by transvaginal ultrasonography was performed (Voluson GE, $730 \mathrm{E}, 7.5 \mathrm{MHz}$ transvaginal probe). We evaluated the size, shape, and echogenicity of the uterus, the uterine cavity outline, endometrial thickness, and the course of the cervical canal. We also carried out a detailed assessment of the ovarian structure, describing the presence, number and size of follicles in the ovaries, which was the basis for selection and division of patients into two groups.

Patients with only small antral follicles $<6 \mathrm{~mm}$ in diameter were selected for group I. This state is described as suppression of ovarian function. Patients with five or more antral follicles $\geq 8 \mathrm{~mm}$ in diameter in each ovary were included in group II.

Patients in both groups were subjected to controlled ovarian hyperstimulation, maintaining a uniform standard of procedure. For the first 7 days, the patients received menopausal gonadotropins (Metrodin, Serono) and recombinant gonadotropins (Gonal-F Serono, Puregon, Organon) at a dose of 150-225 IU FSH/ day. The dose was selected individually depending on initial gonadotropin levels, ultrasonographic appearance of the ovaries, and prior clinical experience. From the eighth day of $\mathrm{COH}$, patients were monitored and gonadotropin dosage was modified depending on the estradiol concentration, follicle size, and endometrial thickness. When most preovulatory follicles reached a diameter of $\geq 19 \mathrm{~mm}$, choriogonadotropin alfa was administered at a dose of $250 \mu \mathrm{g}$ (Ovitrelle, Serono). Oocytes were collected $36 \mathrm{~h}$ after human chorionic gonadotropin (hCG) injection.

Mature oocytes were fertilized by intracytoplasmic sperm injection (ICSI). Eighteen-twenty-one $\mathrm{h}$ after ICSI, the course of fertilization was assessed based on the presence of pronuclei $(\mathrm{PN})$ in oocytes. The presence of two pronuclei (2PN) meant normal fertilization. Abnormally fertilized oocytes (3PN) were eliminated from the culture. Oocytes with one pronucleus (1PN) were left for further culture. Twenty-four and forty-eight $h$ after microinjection, the course of early embryonic development and the quality of the resulting embryos were evaluated. Embryos were classified as A quality when uniform blastomeres with no signs of fragmentation were found; they were classified as B quality when the degree of embryo fragmentation did not exceed $20 \%$ of the surface area. Embryos with fragmentation of $21-50 \%$ were classified as $C$ quality, and $>50 \%$ as D. On the second day after fertilization, two embryos were transferred into the uterus. The remaining embryos remained in culture until the fifth day. 


\section{Statistical analysis}

Data were analyzed using descriptive statistics, Student's $t$ test or Mann-Whitney test (depending on variable distribution), and a test for indicators of the structure. A level of $p<0.05$ was considered statistically significant.

\section{Results}

The study included a total of 635 married couples treated with ICSI due to critically low sperm parameters. Group I included 382 female patients in whom, after a 21-day period of pituitary desensitization with $\mathrm{GnRHa}$, we found only small antral follicles $<6 \mathrm{~mm}$ in diameter. Group II comprised 253 patients in whom, despite pituitary desensitization, we found numerous follicles $>8 \mathrm{~mm}$ in diameter.

The mean age of patients in group I was 30.7 years (21-38 years, SD 3.9) and was not significantly different compared with group II, which was 31.2 years (20-38 years, SD 3.9). All qualified patients had regular menses. Mean menstrual cycle length in group I was 29 days (21-34 days, SD 3.1) and was longer than in group II - 28 days (23-32 days, SD 2.9); $p<0.05$. Mean body mass index (BMI) in the two groups did not differ significantly: group I: $21.7 \mathrm{~kg} / \mathrm{m}^{2}(18.9-$ $24.9 \mathrm{~kg} / \mathrm{m}^{2}$, SD 3); group II: $22.1 \mathrm{~kg} / \mathrm{m}^{2}\left(18.6-24.6 \mathrm{~kg} / \mathrm{m}^{2}\right.$, SD 3.1); $p>0.05$.

The ultrasonographic picture, performed on day 21 after GnRHa administration, showed significant differences in the ovaries, which was the basis for classification into one of two groups. Patients assigned to group II had 5 to 11 antral follicles $>8 \mathrm{~mm}$ in diameter in each of the ovaries (mean $7.8 \mathrm{~mm}$, SD 2.6). Patients in group I did not have follicles $>8 \mathrm{~mm}$. The mean number of follicles from $3 \mathrm{~mm}$ to $6 \mathrm{~mm}$ in diameter in group I was 5.5 (2-11 follicles, SD 4.7), and 4.9 in group II (3-9 follicles, SD 4.2); $p>0.05$.

Mean COHduration in group I was 13.1 days and was significantly longer than in group II, 11.6 days $(p<0.05)$. During $\mathrm{COH}$, gonadotropin use was significantly higher in group I, mean 2340 IU (SD 923) per patient, as compared with group II, mean 2115 (SD 885) IU per patient $(p<0.05)$. Mean $\mathrm{E}_{2}$ concentration in serum on the day of hCG administration was significantly higher in group II (2320 pg/ml, SD 670) compared with group I (2118 pg/ml, SD 811); $p<0.05$. The mean number of preovulatory follicles exceeding $18 \mathrm{~mm}$ in diameter on the day of hCG administration in group I was 15 and was significantly higher than in group II, where it was $13(p<0.05)$.

As a result of ovarian puncture, a total of 4055 oocytes were obtained in group I and 2555 oocytes in group II, of which 3505 and 2214 were M II, and 267 and $141 \mathrm{M} \mathrm{I}$, respectively. We obtained 283 immature oocytes (GV) in group I and 200 in group II. The mean number of mature M II oocytes obtained via ovarian puncture in group I patients was 9.2 and was significantly higher compared with group II, 8.7 M II oocytes $(p<0.05)$. In group I, more M I oocytes were obtained compared with group II $(p<0.05)$. There were no statistically significant differences between the groups in mean number of immature oocytes in the prophase of the first meiotic division (GV).

In group I, a total of $3285 \mathrm{M}$ II and $229 \mathrm{M}$ I oocytes underwent sperm microinjection, after exclusion of 220 dysmorphic M II oocytes and 38 dysmorphic M I oocytes. The percentage of damaged oocytes during ICSI treatment was $1.2 \%$. In group II, a total of 1973 M II and 101 M I oocytes underwent sperm microinjection, after exclusion of 241 dysmorphic M II oocytes and 40 dysmorphic M I oocytes. The percentage of damaged oocytes during ICSI treatment was $0.8 \%$.

There were no significant differences in the mean number of fertilized oocytes between the groups. The fertilization rate, expressed as the ratio of $2 \mathrm{PN}$ to the number of oocytes subjected to sperm microinjection, was $52 \%$ in group I and $56 \%$ in group II $(p>0.05)$ Similarly, there were no differences in the percentages of abnormal fertilization. Detailed data on fertilization in each group are shown in Table 1.

We obtained a total of 2101 embryos in group I and 1291 in group II, of which 306 were two-blastomere (2bl), 191 three-blastomere (3bl), and 1604 four-blastomere (4bl) in group I, and 228 2bl, 152 3bl, 911 4bl in group II. The numbers of $2 \mathrm{bl}$ and $3 \mathrm{bl}$ embryos in the second 24-h period after ICSI were comparable in the two groups. In group I an average of $4.24 \mathrm{bl}$ embryos were obtained, compared to 3.6 in group II, which is a statistically significant difference $(p<0.05)$. Detailed data on the mean number of embryos in the two groups are presented in Table 2 .

The embryo growth rate was significantly faster in group I than II. At $48 \mathrm{~h}$ after fertilization, $76 \%$ of embryos in group I were at the 4-cell stage, 9\% 3-cell, and $15 \% 2$-cell. The corresponding values in group II were $71 \%, 11 \%$ and $18 \%$. In group I, 649 A embryos, 764 B, $458 \mathrm{C}$ and $191 \mathrm{D}$ embryos were obtained

Table 1. Results of oocyte fertilization

\begin{tabular}{|lccc|}
\hline Mean number of & Group I $(n=382)$ & Group II $(n=253)$ & Value of $p$ \\
1PN per patient (SD) & $0.008(0.1)$ & $0.003(0.5)$ & $>0.05$ \\
2PN per patient (SD) & $4.8(3.3)$ & $4.6(3.3)$ & $>0.05$ \\
3PN per patient (SD) & $23(0.06)$ & $20(0.08)$ & $>0.05$ \\
\hline
\end{tabular}


Table 2. Embryo development $48 \mathrm{~h}$ after fertilization

\begin{tabular}{|lccc|}
\hline Mean number of & Group I $(n=382)$ & Group II $(n=253)$ & Value of $p$ \\
2-blastomere embryos per patient (SD) & $0.8(1.3)$ & $0.9(1.3)$ & $>0.05$ \\
3-blastomere embryos per patient (SD) & $0.5(0.85)$ & $0.6(0.86)$ & $>0.05$ \\
4-blastomere embryos per patient (SD) & $4.2(0.1)$ & $3.6(0.1)$ & $<0.05$ \\
\hline
\end{tabular}

Table 3. Embryo quality $48 \mathrm{~h}$ after fertilization

\begin{tabular}{|lccc|}
\hline Mean number of & Group I $(n=382)$ & Group II $(n=253)$ & Value of $p$ \\
A quality embryos (SD) & $1.7(2)$ & $1.6(1.9)$ & $>0.05$ \\
B quality embryos (SD) & $2(1.8)$ & $1.7(1.9)$ & $<0.05$ \\
C quality embryos (SD) & $1.2(1.6)$ & $1.1(1.5)$ & $>0.05$ \\
D quality embryos (SD) & $0.5(1.1)$ & $0.4(0.9)$ & $>0.05$ \\
\hline
\end{tabular}

at $48 \mathrm{~h}$ after fertilization. In group II, we obtained 405 A embryos, 430 B, 278 C, and 101 D.

The numbers of $\mathrm{A}, \mathrm{C}, \mathrm{D}$ quality embryos were comparable between the groups $(p>0.05)$. There were more B quality embryos in group I than II $(p>0.05)$. Detailed data on the mean number of particular types of embryos are presented in Table 3.

On the second day after fertilization, embryos were transferred. We did not observe a statistically significant difference in the average number of embryos transferred in group I (2.04) and group II (2.05). The percentage of transfers in which the embryos were classified as the highest quality, A and B, was comparable; in group I it was $97 \%$ and in group II $98 \%$.

Of the 2101 embryos in group I, 1283 embryos remained after the transfer, from which we further cultured 385 blastocysts (30\%). In the second group, of 1291 embryos 693 remained after transfer, from which we cultured 83 blastocysts (12\%). We found statistically significant differences in the number of blastocysts cultured $(p<0.05)$.

\section{Discussion}

Controlled ovarian hyperstimulation is an integral part of infertility treatment through assisted reproduction techniques. The main objective of using $\mathrm{COH}$ is to obtain oocytes with development potential that gives the best chance of getting pregnant and having a healthy baby. Currently, there are many $\mathrm{COH}$ modifications, which are called protocols. Analyses show that the most effective is the so-called "long protocol" [5]. In this protocol, GnRHa is used to obtain pituitary desensitization, and then exogenous gonadotropins are used to obtain a simultaneous increase in a few dozen oocytes. The ongoing exposure to GnRHa throughout $\mathrm{COH}$ prevents the $\mathrm{LH}$ peak, making it possible to plan the timing of ovulation. In practice, this enables the collection of oocytes from the ovaries and their fertilization outside the human organism.
Despite wide use of the long protocol for infertility treatment, some of its aspects are still not fully understood. In particular, little is known about the impact of this treatment on the mechanisms related to the recruitment and selection of antral follicles, from which oocytes will be obtained after a period of stimulation. In practice, this problem is related to the initial stage of treatment with GnRHa and designating inclusion criteria for stimulating with exogenous gonadotropins. The issue of the functional status of the ovaries after initial exposure to GnRHa and its impact on the course of $\mathrm{COH}$, the embryological and clinical results of treatment are particularly important. It should be noted that this topic had not yet been examined, and the available literature refers to it in a piecemeal fashion.

Ovarian stimulation protocols, including the long protocol, bypass the natural stages of selection of gonadotropin-dependent follicles. This may affect treatment efficacy. In the natural cycle, corpus luteum spurium atrophy is accompanied by a decrease in progesterone concentrations, which leads to increased FSH secretion. Increased FSH concentration results in the recruitment of small antral follicles producing $\mathrm{E}_{2}$, which then inhibits the secretion of FSH, and therefore one healthy follicle with the highest sensitivity to gonadotropins is selected. The remaining follicles undergo atresia [6]. In properly functioning ovaries, atretic follicles degenerate and undergo apoptosis. In polycystic ovaries, the mechanism of atresia, similarly to recruitment and selection, does not function properly. As a result, many antral follicles $2 \mathrm{~mm}$ to $14 \mathrm{~mm}$ in diameter are present.

The exogenous gonadotropins administered during $\mathrm{COH}$ eliminate mechanisms of natural selection and lead to an increase in the number of antral follicles, whose sensitivity threshold to gonadotropins corresponds with the FSH dose used. This is a significant problem for patients with polycystic ovaries. Scientific and clinical observations have found that only antral 
follicles $<6 \mathrm{~mm}$ contain oocytes of preserved reproductive potential [7]. In the case of antral follicles $>8 \mathrm{~mm}$ in diameter, researchers have found various degrees of atretic changes in granule cells and oocytes [7]. The initial atretic changes are usually functional and can be very difficult to identify in the microscopic evaluation. It only becomes apparent at a later stage as a lack of fertilization, embryo development cessation, implantation failure or miscarriage. Therefore, starting the induction of multiple ovulation in the ovaries that contain many follicles at different stages of development, there is the possibility of obtaining a pool of oocytes with more or less severe atretic changes.

In our study, patients in both groups underwent $\mathrm{COH}$, maintaining a uniform standard of procedure. Despite this, the duration of $\mathrm{COH}$ in group I was longer by about 2 days. Given the difference in mean follicle size between the groups at the beginning of stimulation and the fact that the growth rate of follicles is fairly constant at an average of 1-2 mm per day, the difference in the duration of $\mathrm{COH}$ is understandable. As a result of ovarian stimulation, group I had significantly more preovulatory follicles $\geq 18 \mathrm{~mm}$ in diameter compared with group II, with a similar number of follicles at the beginning of stimulation. The final difference may therefore result from a greater efficiency of ovulation induction with respect to antral follicles $<6 \mathrm{~mm}$, or from increased atresia in follicles $>8 \mathrm{~mm}$ at the start of stimulation.

As a result of follicular puncture, we obtained significantly more M II oocytes in group I than in group II. A similar trend was observed for M I oocytes. It appears that the higher mean number of M II and $\mathrm{M}$ I oocytes in group I is the result of a greater number of preovulatory follicles $\geq 18 \mathrm{~mm}$ on the day of hCG administration and a higher degree of their development synchronization. This is indicated by the approximate number of obtained immature oocytes in the prophase of the first meiotic division and atrophy of the nuclear membrane. In group II, despite the higher total number of follicles, oocyte recovery was lower. This suggests that some of the follicles in this group did not contain oocytes.

We found no significant differences between the groups in oocyte fertilization. The conception rate, expressed as the ratio of $2 \mathrm{PN}$ to the number of oocytes subjected to sperm microinjection, was $52 \%$ in group I and 56\% in group II, which is an acceptable value, similar to literature data [8]. Similarly, there were no differences in the percentages of abnormal fertilization. The adjusted conception rate, expressed as the ratio of the number of obtained embryos to the number of cells treated by ICSI, was also comparable between the groups.

The numbers of two- and three-blastomere embryos in the second 24-h period after ICSI were comparable in the two groups. We found a significantly higher percentage of four-blastomere embryos in group I. This indicates a higher rate of embryonic development in this group. There were no significant differences in the percentage of embryos, evaluated by morphological criteria on the second day after fertilization, except for B quality embryos that were found more frequently in patients of group I. According to Van Royen et al., embryos with the greatest development potential are 4-to-5-blastomere embryos on the second day after fertilization without multinucleated blastomeres and $<20 \%$ fragmentation [9]. This description corresponds to A and B quality embryos. Analysis shows that in group I there were significantly more A and B quality embryos. This may affect the treatment results, because it seems that the normal embryo chromosomal arrangement is correlated with the rate and symmetry of embryonic divisions. Embryos with a too slow [10] or too fast [11] division rate are often aneuploid. In the case of embryos obtained via an in vitro fertilization program, aneuploidy is found in $30-65 \%$, and mosaicism in $17-43 \%$ [12]. The degree of fragmentation of the blastomeres is also positively correlated with chromosome disorders [13]. In this situation, evaluation of the quality and the rate of embryonic development is important in the selection of embryos for transfer. As indicated by the results of our study, it is important to analyze the quality of the embryos transferred into the uterus. The percentage of transfers of embryos of only the highest quality (A, B) was comparable. In group I, it was $97 \%$, and in group II, 98\%; therefore, the effect of the quality of the transferred embryos on differences in outcome between the groups is minimal.

One parameter that indicates treatment quality and the development potential of oocytes is the percentage of blastocysts formed in extended culture. In our study, this percentage was significantly higher in group I. This indicates a higher development potential in embryos remaining in in vitro culture. In the case of embryos transferred into the uterus and developing in vivo, we found significantly higher pregnancy rates and greater implantability in group I. This indicates a higher embryo development potential and indirectly is evidence of a better procedure at the initial stages of treatment, the objective of which is to obtain suppression of ovarian function.

In light of this, adequate levels of suppression of ovarian function at the start of controlled ovarian hyperstimulation are an important prerequisite for achieving optimal embryological results of infertility treatment through assisted reproduction techniques.

\section{Conclusions}

The results of the present study indicate that the functional status of the ovaries before controlled ovarian hyperstimulation plays a pivotal role in the course and outcome of treatment. The type and rate 
of development of embryos depend on the degree of suppression of ovarian function before controlled ovarian hyperstimulation.

\section{References}

1. Ferraretti AP, Goossens V, de Mouzon J et al. Assisted reproductive technology in Europe, 2008: results generated from European registers by ESHRE. Hum Reprod 2012; 27: 2571-2584.

2. Al-Inany HG, Abou-Setta AM, Aboulghar M. Gonadotrophin-releasing hormone antagonists for assisted conception: a Cochrane review. Reprod Biomed Online 2007; 14: 640-649.

3. Loutradis D, Drakakis P, Kallianidis K et al. The effect of the duration of GnRH-agonist down regulation before ovarian stimulation on the biological and clinical outcome after intracytoplasmic sperm injection. Eur J Obstet Gynecol Reprod Biol 1998; 80: 251-255.

4. Ron-El R, Herman A, Golan A et al. Follicle cyst formation following long-acting gonadotropin-releasing hormone analog administration. Fertil Steril 1989; 52: 1063-1066.

5. Daya S. Gonadotropin releasing hormone agonist protocols for pituitary desensitization in in vitro fertilization and gamete intrafallopian transfer cycles. Cochrane Database Syst Rev 2000; CD001299.

6. Schreiber JR, Nakamura K, Truscello AM et al. Progestins inhibit FSH-induced functional $\mathrm{LH}$ receptors in cultured rat granulosa cells. Mol Cell Endocrinol 1982; 25: 113-124.

7. Takahashi K, Eda Y, Abu-Musa A et al. Transvaginal ultrasound imaging, histopathology and endocrinopathy in patients with polycystic ovarian syndrome. Hum Reprod 1994; 9: 1231-1236.

8. Flaherty SP, Payne D, Swann NJ et al. Aetiology of failed and abnormal fertilization after intracytoplasmic sperm injection. Hum Reprod 1995; 10: 2623-2629.

9. Van Royen E, Mangelschots K, De Neubourg D et al. Characterization of a top quality embryo, a step towards single-embryo transfer. Hum Reprod 1999; 14: 2345-2349.

10. Munne S, Grifo J, Cohen J et al. Chromosome abnormalities in human arrested preimplantation embryos: a multiple-probe FISH study. Am J Hum Genet 1994; 55: 150-159.

11. Harper JC, Robinson F, Duffy S et al. Detection of fertilization in embryos with accelerated cleavage by fluorescent in-situ hybridization (FISH). Hum Reprod 1994; 9: 17331737.

12. Delhanty JD, Griffin DK, Handyside AH et al. Detection of aneuploidy and chromosomal mosaicism in human embryos during preimplantation sex determination by fluorescent in situ hybridisation (FISH). Hum Mol Genet 1993; 2: 1183-1185.

13. Magli MC, Gianaroli L, Ferraretti AP. Chromosomal abnormalities in embryos. Mol Cell Endocrinol 2001; 183 Suppl. 1: S29-S34

\section{Address for correspondence:}

Cezary Grygoruk MD

Center for Reproductive Medicine Bocian ul. Szpitalna 23, 15-267 Bialystok, Poland

Phone: +48 857447700

E-mail: cezary.grygoruk@gmail.com 